\title{
Variability in the water, sodium, potassium, and chloride content of human skeletal muscle
}

\author{
C. T. G. FLEAR ${ }^{1}$, R. G. CARPENTER, AND IRENÉ FLORENCE \\ From the Queen Elizabeth Hospital, Birmingham, and the \\ Department of Human Ecology, Cambridge
}

SYNOPSIS Muscle from 47 individuals was analysed for water, sodium, chloride, potassium, and fat In 35 patients, samples were taken from three sites in one muscle, and in five from several muscies The average composition of different muscles differed, even in the same individual and the cofnposition of samples varied considerably. Variability is the larger the more diverse the material. Coefficients of variation of muscle constituents are given for material from a biopsy, a muscle $\vec{e}_{e}^{-a}$ subject, or a given muscle in any subject. Some of these are large.

Variability in the composition of samples is shown to be largely orderly. Water is closely correlated with tissue content of sodium plus potassium; sodium and chloride contents of samples show a positive correlation; potassium and sodium contents are strongly negatively correlated. Residmal stochastic variability is small. Thus, when account is taken of the sodium content of a biopsy, the coefficient of variation for a potassium estimate falls from $12 \%$ to about $6 \%$. Some practieal implications are deduced.

In a number of clinical studies, samples of human skeletal muscle have been analysed for water and electrolytes, and certain conclusions have been drawn about the composition of cells and tissues of the body in disease and at times individual diagnoses essayed. The validity of conclusions reached rests not only on the reliability of the analytical techniques used but also on knowing the variability in composition that exists within a muscle and the differences encountered in normal individuals. A preliminary of some of this material has been presented briefly elsewhere (Flear and Florence, 1963).

\section{MATERIAL AND METHODS}

Seven individuals admitted for minor surgery consented to have single biopsies taken from the gastrocnemius or deltoid or both muscles. Samples were also taken from muscles exposed at operation in 36 individuals in good condition and in four whose general condition was rather poor. Each muscle was sampled at three widely spaced sites. None of the patients had overt disturbance of electrolyte metabolism and none had neuromuscular disorders. Details are presented in Table I.

Samples were taken from the pectoralis major in patients undergoing radical mastectomy. They were cut 'Present address: Department of Clinical Biochemistry, The Royal Victoria Infirmary, Newcastle upon Tyne.

Received for publication 3 March 1964. after the muscle was dissected from the chest wall $\frac{2}{\mathbb{D}} \mathrm{d}$ removed. All other samples were cut with a scaftel immediately after the muscle had been exposed, and using forceps were placed directly into sterile, acidwashed containers. Three slices were cut from eatch muscle biopsy, and were weighed on a $50 \mathrm{mg}$. torsion

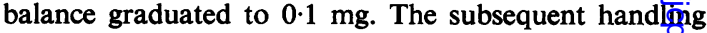
and analysis of these pieces of muscle has already been described (Flear and Florence, 1961).

The water and electrolyte contents of samples are expressed as amounts per kilogram wet weight, Ger kilogram fat-free wet weight, per kilogram dry weight, per kilogram fat-free dry weight, and per litre of tisGue water. Variability in the amount of water, sodium, potassium, or chloride in muscle samples is in each case cited as a coefficient of variation which is the standard jeviation of a group of observations expressed as a percentage of their mean.

No attempt was made to partition tissue water, sodium, and potassium into cellular and extracellular component's from calculations involving the assumption that chloride is excluded from cells, as we believe that this assumption is unsound.

\section{FINDINGS}

AVERAGE COMPOSITION OF SKELETAL MUSCLES average composition of various skeletal muscles presented in Table II and Figure 1. Some differenees 
TABLE I

MUSCLE BIOPSY MATERIAL OBTAINED

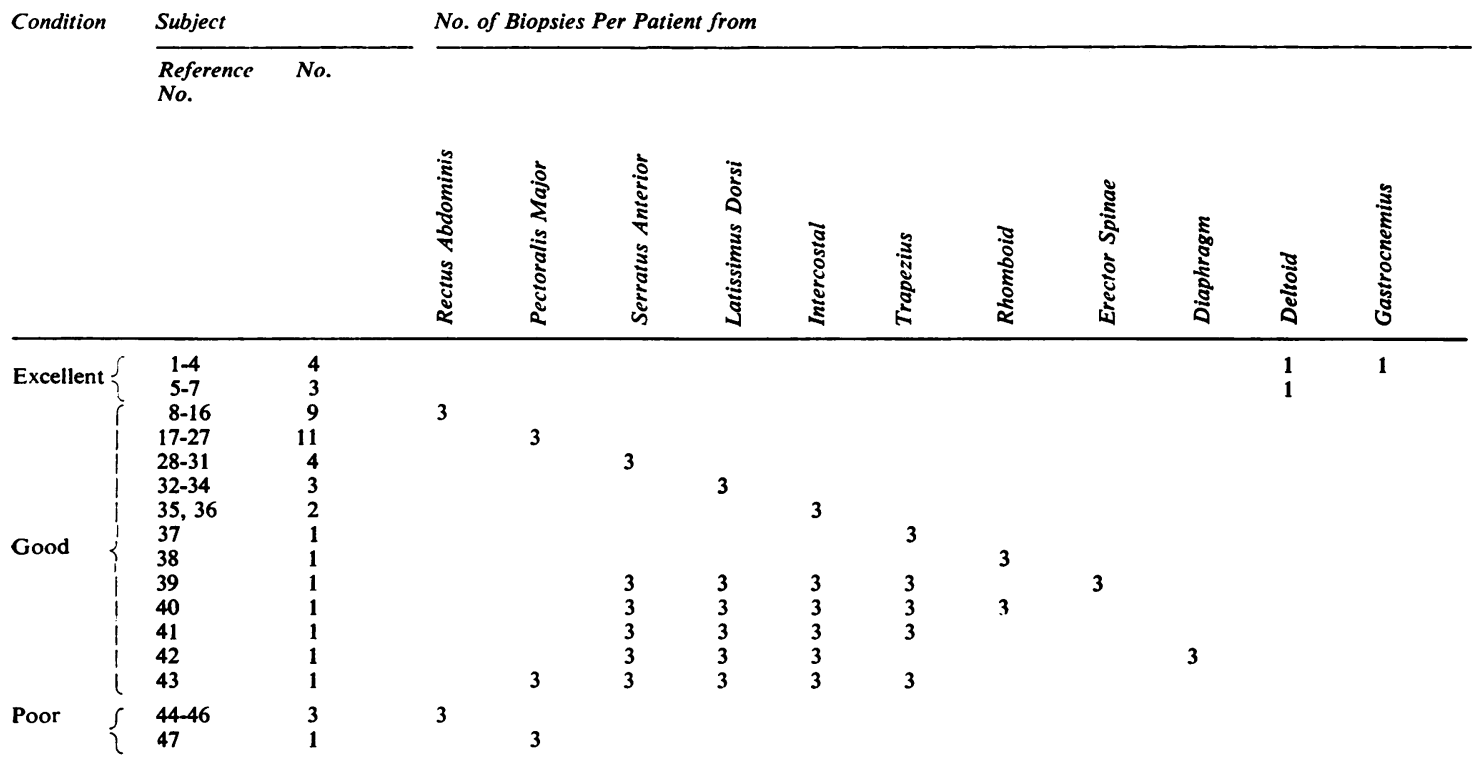

For subjects 8 to 47 the three biopsies per muscle were taken at the same time from widely different locations in the muscle. Each biopsy was divided into three slices which were analysed independently for sodium, potassium, chloride, and water, with following exceptions:Chloride was not estimated in biopsies from subjects 39-42, 44-7.

Water content was determined in only two of three slices of each biopsy from subjects 8-38, 43-47.

Fat was estimated in all slices of muscle from subjects 1-7, 39-43.

TABLE II

COMPOSITION OF VARIOUS MUSCLES IN 43 CONTROL SUBJECTS

\begin{tabular}{|c|c|c|c|c|c|c|c|c|c|c|c|c|}
\hline \multirow[t]{2}{*}{ Muscle } & \multicolumn{3}{|c|}{ Water $(\mathrm{ml} . / 100 \mathrm{~g})}$. & \multicolumn{3}{|c|}{ Sodium ( $m E q)}$. & \multicolumn{3}{|c|}{ Potassium (mEq.) } & \multicolumn{3}{|c|}{ Chloride (mEq.) } \\
\hline & Mean & S.E. & No. ${ }^{1}$ & Mean & S.E. & No. & Mean & S.E. & No. & Mean & S.E. & No. \\
\hline Rectus abdominis & $77 \cdot 1$ & 0.53 & 9 & $28 \cdot 5$ & $1 \cdot 50$ & 9 & $86 \cdot 7$ & $2 \cdot 43$ & 9 & $21 \cdot 5$ & $1 \cdot 28$ & 9 \\
\hline Pectoralis major & 76.6 & 0.37 & 12 & $27 \cdot 5$ & 1.30 & 12 & $93 \cdot 1$ & $\begin{array}{l}2.43 \\
1.87\end{array}$ & 12 & $21 \cdot 4$ & $\begin{array}{l}1 \cdot 20 \\
1 \cdot 11\end{array}$ & $\begin{array}{r}9 \\
12\end{array}$ \\
\hline Serratus anterior & $76 \cdot 3$ & 0.79 & 9 & $30 \cdot 4$ & $2 \cdot 15$ & 9 & $89 \cdot 4$ & 1.77 & 9 & $18 \cdot 7$ & $2 \cdot 25$ & 5 \\
\hline Latissimus dorsi & $75 \cdot 9$ & 0.88 & 8 & $35 \cdot 5$ & $2 \cdot 75$ & 8 & $88 \cdot 8$ & $2 \cdot 38$ & 8 & $24 \cdot 7$ & - & 4 \\
\hline Intercostal & $73 \cdot 8$ & 1.56 & 7 & $42 \cdot 2$ & 4.03 & 7 & $74 \cdot 9$ & $4 \cdot 10$ & 7 & $22 \cdot 3$ & - & 3 \\
\hline Trapezius & $77 \cdot 5$ & 0.53 & 5 & 30.9 & $2 \cdot 15$ & 5 & 92.8 & $3 \cdot 29$ & 5 & $21 \cdot 3$ & - & 2 \\
\hline Rhomboid & $77 \cdot 6$ & - & 2 & $35 \cdot 0$ & - & 2 & 94.0 & - & 2 & $17 \cdot 0$ & - & 1 \\
\hline Erector spinae & $74 \cdot 6$ & - & 1 & 26.0 & - & 1 & 90.0 & - & 1 & & & \\
\hline Diaphragm & $75 \cdot 7$ & - & 1 & $32 \cdot 3$ & - & 1 & 88.8 & - & 1 & & & \\
\hline Deltoid & 73.0 & $1 \cdot 33$ & 7 & $49 \cdot 3$ & 3.03 & 7 & 68.4 & 3.92 & 7 & $42 \cdot 8$ & $2 \cdot 15$ & 7 \\
\hline Gastrocnemius & 75.9 & $1 \cdot 20$ & 4 & $35 \cdot 2$ & 6.44 & 4 & $83 \cdot 3$ & $6 \cdot 77$ & 4 & 33.8 & $5 \cdot 31$ & 4 \\
\hline
\end{tabular}

${ }^{1}$ Number of subjects; the mean value taken for each individual is based upon three values, one from each site sampled.

The amounts of electrolytes are those contained in $1 \mathrm{~kg}$. of wet tissue.

in composition are not attributable to sampling. Deltoid and intercostal muscles differ most in composition and, in both, water and potassium contents are low and sodium content is high.

Significant differences were also seen between the average composition of different muscles in the same individuals (Fig. 2).

VARIABILITY OF WATER, SODIUM, POTASSIUM, AND CHLORIDE EACH CONSIDERED INDEPENDENTLY AS might be expected, variability is larger the more diverse the material; biopsies from the same muscle are more similar than from different muscles in the same subject, or from the same muscle in different subjects. Findings are summarized in Table III.

Column 1, Table III, presents variability found in multiple estimates of a single muscle extract (Flear and Florence, 1961). As another check on analytical errors, varying known amounts of sodium and potassium were added as chlorides to an extract of muscle. The ratio of sodium to potassium was kept constant in all solutions. In 18 observations, 


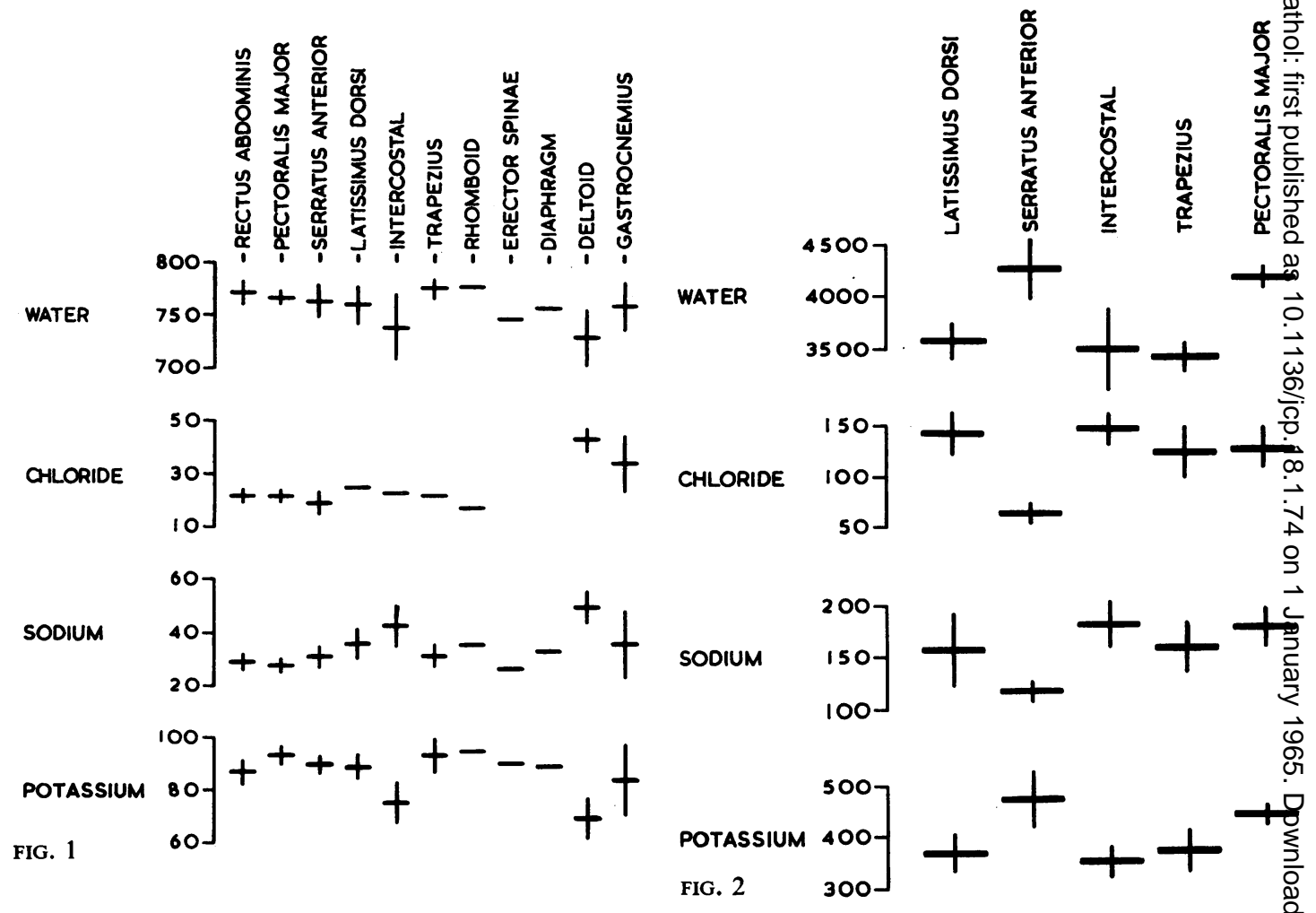

FIG. 1. Average wet weight composition of 11 skeletal muscles (Table II); the vertical lines extend for 2 standard erro on either side of the means.

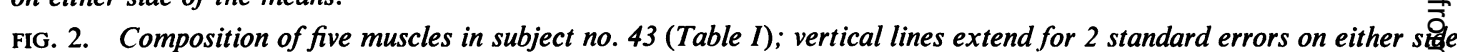
of the means (horizontal lines). Amounts are quoted as $\mathrm{G}$. (water) or $\mathrm{mEq}$. (Na,K,Cl) per kilogram fat-free dry weight tissue.

estimates of sodium added averaged $1.5 \%$ less than actual additions (S.E. 0.02\%); estimates of potassium averaged $0.9 \%$ less (S.E. $0.01 \%$ ) than actual additions.

Column 2, Table III, shows the coefficient of variation of observations when samples are from the same biopsy. These figures are larger than those previously given (Flear and Florence, 1961) whieh were calculated at the time when techniques we being developed. We should perhaps regard the present figures as more appropriate to routio situations, although we cannot exclude the possibility that differences in coefficients of variation $\mathrm{Fe}$ flect clinical differences in subject samples, or eve्sn

TABLE III

COEFFICIENTS OF VARIATION OF MUSCLE CONSTITUENTS PER KG. WET TISSUE ACCORDING TO THE ORIGIN OF MATERIAL

Electrolyte Coefficients of Variation (\%) of Single Estimates of Biopsy Material from

\begin{tabular}{|c|c|c|c|c|c|c|}
\hline & \\
\hline & $\begin{array}{l}\text { Same Nitric Acid } \\
\text { Muscle Extract on } \\
\text { Different Days } \\
1\end{array}$ & $\begin{array}{l}\text { Different Slices } \\
\text { Same Biopsy } \\
2\end{array}$ & $\begin{array}{l}\text { Different Sites in } \\
\text { Same Muscle } \\
3\end{array}$ & $\begin{array}{l}\text { Different Muscles in } \\
\text { Same Subject } \\
4\end{array}$ & $\begin{array}{l}\text { Same Muscle in } \\
\text { Different Subjects } \\
5\end{array}$ & 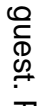 \\
\hline $\begin{array}{l}\text { Potassium } \\
\text { Sodium } \\
\text { Chloride } \\
\text { Water }\end{array}$ & $\begin{array}{l}0.46 \\
0.42 \\
- \\
-\end{array}$ & $\begin{array}{r}6 \cdot 1 \\
13 \cdot 7 \\
12 \cdot 6 \\
2 \cdot 1\end{array}$ & $\begin{array}{r}8 \cdot 1 \\
18 \cdot 8 \\
18 \cdot 9 \\
3 \cdot 1\end{array}$ & $\begin{array}{l}13 \cdot 1 \\
24 \cdot 7 \\
-\quad \\
3 \cdot 5\end{array}$ & $\begin{array}{r}12 \cdot 0 \\
26 \cdot 8 \\
31 \cdot 3 \\
4 \cdot 2\end{array}$ & $\begin{array}{l}\frac{0}{D} \\
\frac{\text { D }}{D}\end{array}$ \\
\hline
\end{tabular}

Coefficients of variation are derived on the basis of the random effects model described by Mood (1950), details of the model used will be given elsewhere (Carpenter and Flear). Methods were somewhat unorthodox, but used all our material and are algebraically satisfactory (Carpener). 


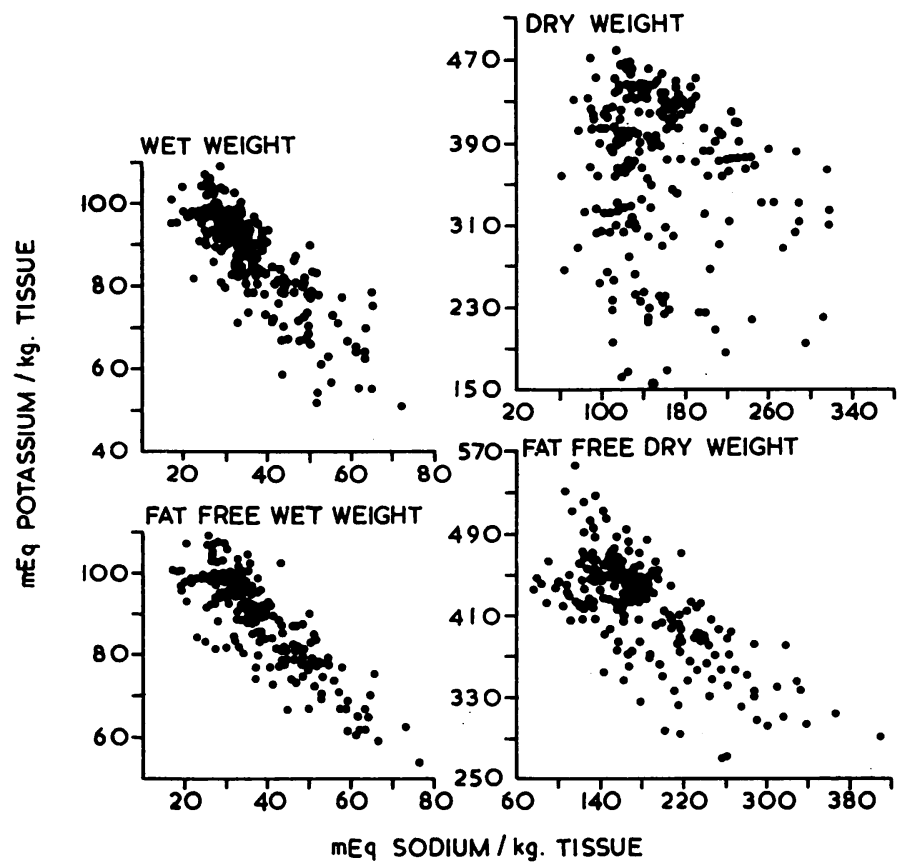

FIG. 3. Relation between sodium and potassium in material from nine muscles and 12 subjects (nos. 1-7 and 39-43 in Table I). Sodium and potassium contents of samples are presented using four different reference bases.

differences in muscles sampled. Comparison with column 1 shows how much local variation there is in muscle composition.

Column 3, Table III, presents the coefficients of variation of single observations when the site of the biopsy in a muscle is arbitrary. Taking samples without regard to their site increases the coefficients of variation by about $30 \%$; the samples from which these were derived were all taken on a single occasion. As biopsies taken on separate occasions are unlikely to come from identical sites, these coefficients of variation afford estimates of the variability to be expected when repeated biopsies are taken from the same muscle. Where successive biopsies from a patient are not all from the same muscle, choice of muscle being arbitrary, coefficients of variation are those given in column 4 of Table III. They are between 28 and $66 \%$ larger than those shown in column 3 .
When biopsies have not previously been taken from a patient, composition can only be compared with that of similar muscles in control subjects. Variability in composition of samples from a given muscle in a group of control subjects is shown in column 5 of Table III. The coefficient of variation of $12 \%$ for potassium observations implies that the potassium content of a biopsy must be about $24 \%$ below average before it can be considered significantly reduced.

Possibly these data exaggerate differences that would be found in normal life; four of the 34 subjects were in poor condition (Table I), and all were undergoing surgery of some kind. Variation found on sampling different sites in a muscle in unlikely to be exaggerated. It is responsible for some $60 \%$ of both the total variation found when a given muscle is sampled in different subjects and of that found when different muscles are sampled in one individual.

TABLE IV

RELATIONSHIP BETWEEN SODIUM AND POTASSIUM CONTENTS OF SAMPLES OF MUSCLE USING REFERENCE BASES SHOWN

\begin{tabular}{|c|c|c|c|c|c|c|c|c|}
\hline \multirow[t]{2}{*}{ Reference Base } & \multirow{2}{*}{$\begin{array}{l}\text { No. of } \\
\text { Samples }\end{array}$} & \multicolumn{2}{|c|}{ Means } & \multirow[t]{2}{*}{ Correlation } & \multicolumn{4}{|c|}{ Regression of $\mathrm{K}$ on $\mathrm{Na}$} \\
\hline & & $\overline{N a}$ & $\bar{K}$ & & Slope & (S.E.) & $\begin{array}{l}\text { Residual } \\
\text { S.D. = S }\end{array}$ & $\begin{array}{l}\text { Coefficient } \\
\text { of Variation } \\
(\%)(100 S / \bar{K})\end{array}$ \\
\hline $\begin{array}{l}\text { Kilogram of wet weight } \\
\text { Kilogram of fat-free wet weight } \\
\text { Kilogram of fat-free dry weight } \\
\text { Litre of tissue water }\end{array}$ & $\begin{array}{l}203 \\
198 \\
199 \\
201\end{array}$ & $\begin{array}{r}36 \cdot 4 \\
38 \cdot 0 \\
180 \cdot 5 \\
48 \cdot 2\end{array}$ & $\begin{array}{r}85 \cdot 7 \\
89 \cdot 0 \\
418 \cdot 9 \\
113 \cdot 1\end{array}$ & $\begin{array}{l}-0.776 \\
-0.842 \\
-0.706 \\
-0.821\end{array}$ & $\begin{array}{l}-0.853 \\
-0.838 \\
-0.626 \\
-0.865\end{array}$ & $\begin{array}{l}0 \cdot 049 \\
0 \cdot 038 \\
0 \cdot 044 \\
0 \cdot 043\end{array}$ & $\begin{array}{r}7 \cdot 4 \\
6.2 \\
36 \cdot 5 \\
8 \cdot 6\end{array}$ & $\begin{array}{l}8 \cdot 6 \\
6 \cdot 9 \\
8 \cdot 7 \\
7 \cdot 6\end{array}$ \\
\hline
\end{tabular}




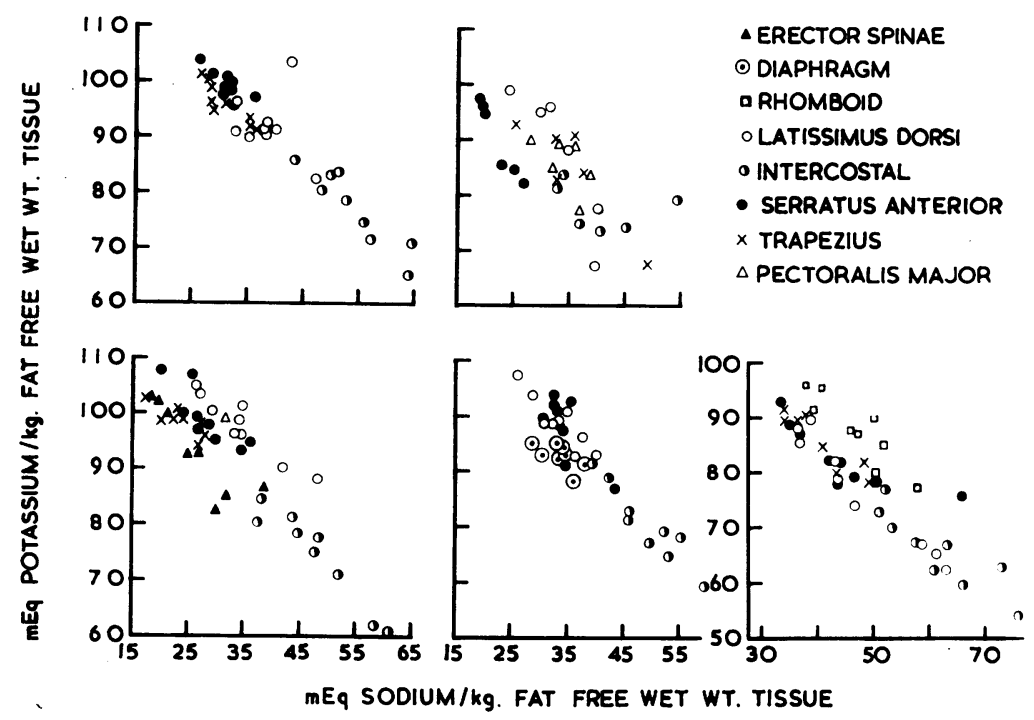

FIG. 4. Relationship between sodium and potassium (data from subjects 39-43 in Table I).

Coefficients of variation shown in Table III are pooled estimates based on several muscles and subjects. Before forming these pooled estimates the coefficients of variation for the individual muscles or subjects were compared, but no notable differences were found.

USE OF DIFFERENT REFERENCE BASES Where possible we have compared estimates of variability obtaining when amounts of sodium, potassium, and chloride

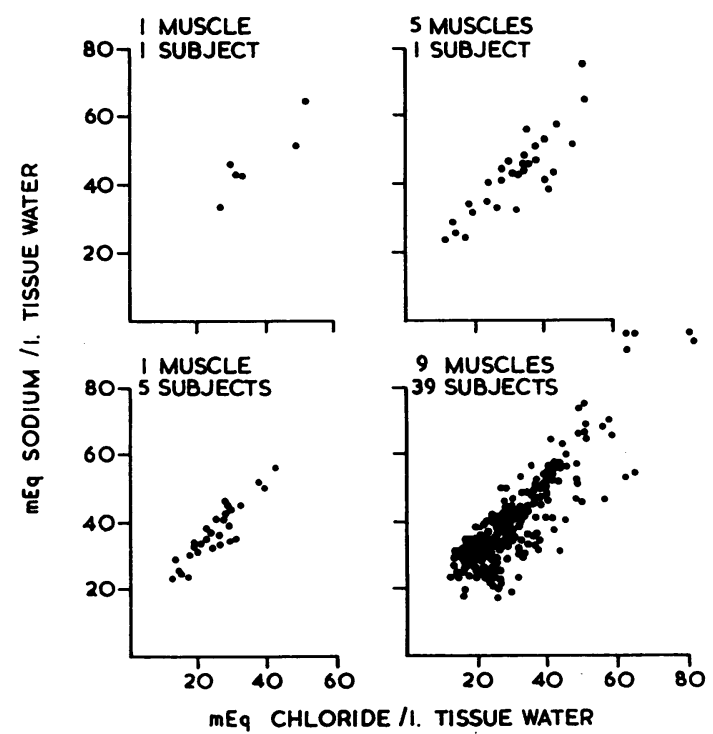

FIG. 5. Sodium and chloride contents (mEq./l. tissue water) of samples of muscle from subjects $1-38$ and 43 (Table I). in samples are quoted per kilogram wet, dry, fat free wet, and fat-free dry weight of tissue; they wereo substantially the same in each case. When tissuer water is expressed as amounts per kilogram dry weight or fat-free dry weight of tissue, variability is greater than when expressed as amounts per kilo gram wet weight. Tissue water contributes aboun $75 \%$ of total wet weight; consequently when watero content is referred to wet weight of tissue, variability is reduced.

Analysis of published data of other investigator (Talso, Spafford, and Blaw, 1953a, b; BarnesGordon, and Cope, 1957; Litchfield and Gaddie 1958) shows a similar lack of effect of reference bases on the variability of sodium, potassium, and chloride.

RELATIONSHIP BETWEEN MUSCLE CONSTITUENTS Three very striking relationships were apparent betweerf constituents of muscle samples; negative cor 7 relations between sodium and potassium (Figs. and 4 and Table IV), positive correlations between chloride and sodium (Fig. 5) and similarly for atP reference bases, and also between water and the sum of sodium plus potassium (Fig. 6), which is. equally present when dry weight of tissue is the reference base. When data were grouped by muscles or by subject, water content of samples sometimes exhibited a number of other relationships with sodium, with potassium, and with the combined concentration of sodium and potassium in tissue water.

The negative correlation between sodium an $\overrightarrow{\mathrm{B}}$ potassium contents of samples is evident where 


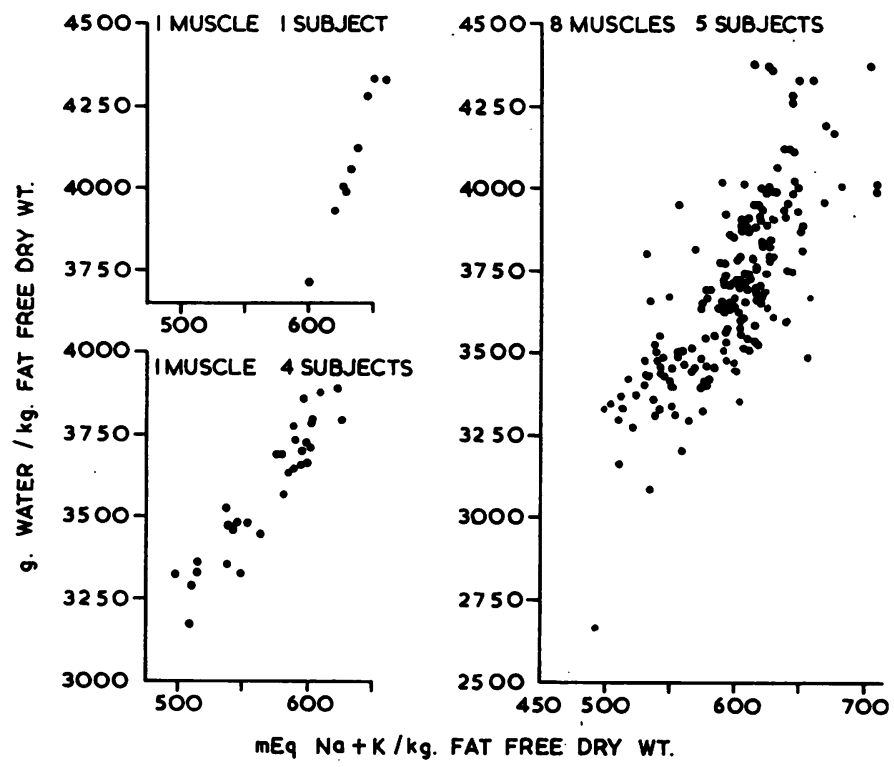

FIG. 6. Relationship between muscle contents of water and the sum of sodium and potassium.

these amounts are expressed per kilogram wet, fatfree wet or fat-free dry weight of tissue, or per litre of tissue water, but not when quoted per kilogram dry weight of tissue (Fig. 3) ${ }^{1}$.

Variability in a sample content of water and electrolyte is thus largely orderly. The considerable significance that this holds for appraisal of the composition of a sample will be considered in some detail for potassium.

APPRAISAL OF POTASSIUM CONTENT OF SAMPLES The mean potassium content of samples with a given sodium content is given by the line calculated from the regression of potassium on sodium content of samples. This regression was calculated for each biopsied muscle (Fig. 7). Analyses of variance showed that in no instance were the several regression lines homogeneous, although slopes were homogeneous when fat-free dry weight is used as reference base. It is, however, possible to show that if the muscles are regarded as a random sample of muscle, and subject to one or two other not unreasonable conditions, the heterogeneity of the regression coefficients about the pooled mean within muscle regression coefficients can be regarded as merely introducing extra random variation. If this is done the residual standard deviation is only inflated by $12 \%$.

The regression of $\mathrm{K}$ on $\mathrm{Na}$ was therefore calculated, pooling data from different muscles (Table IV). For the four reference bases shown in Table IV, correlations are all highly significant $(0.001>\mathrm{P})$.

'It is not an artefact. With the flame photometer used, the simultaneous presence of either cation leads to overestimation of the other. In extent, this depends both on the ratio of the cations and on their absolute concentration. Overestimation scarcely varies with the ratios met $(\mathrm{Na} / \mathrm{K}=0.14$ to 1.40 ; Fig. 3$)$ and, at the working concentrations of sodium and potassium used, is about $4 \%$ for $\mathrm{Na}(3$ to $5 \%$ ), $0.5 \%$ for $\mathrm{K}$. In the presence of phosphate both cations are underestimated; potassium to a greater extent ( 3 to $4 \%$ ) than sodium ( 1 to $2 \%$ ) with concentrations of phosphate of the order found in our muscle extracts.

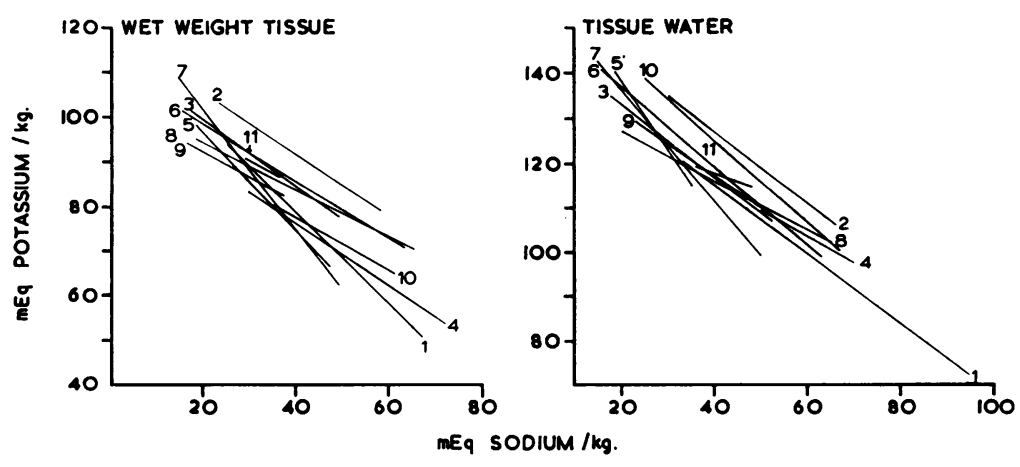

FIG. 7. Relationships between sodium and potassium contents of samples of muscle from subjects 1-43 (Table I); calculated lines for the regression of potassium on sodium. The muscles are identified thus:$1=$ gastrocnemius, $2=$ rhomboid, 3 = trapezius, $4=$ intercostal, $5=$ rectus abdominis, 6 = latissimus dorsi, 7 = pectoralis major, 8 = serratus anterior, $9=$ erector spinae, $10=$ deltoid, 11 = diaphragm. 
Using the appropriate regression line, potassium content of a biopsy may be compared with that predicted for a sample with the same sodium content. Confidence limits define the distribution of control observations about the regression lines. Alternatively these regression relations may be used to adjust the observed potassium content of a biopsy to that which it would have been had its sodium content been average. For example, suppose the sodium and potassium contents of a biopsy are 26.4 and $77.1 \mathrm{mEq} . / \mathrm{kg}$. wet weight respectively. The potassium content is only $10 \%$ below the average shown in Table IV and the sodium content $28 \%$ below the average of $36.4 \mathrm{mEq} . / \mathrm{kg}$. (Table IV); neither is significantly low when considered alone (see Table III). The expected potassium content of the sample, had sodium content been average, i.e. $\mathrm{K}$ (adjusted) is :

$\mathrm{K}$ (adjusted) $=$ observed $\mathrm{K}-$ (slope of regression

$$
\begin{aligned}
& x(\text { observed } \mathrm{Na}-\text { average } \mathrm{Na}) \\
= & 77 \cdot 1+0.853(26.4-36.4) \\
= & 68.6 .
\end{aligned}
$$

This value is $20 \%$ below normal, a significant reduction (see Table IV).

Coefficients of variation of unadjusted and adjusted potassium values were calculated for the nine observations from each muscle sampled in subjects 39 to 43 ; data were referred to each of the four references bases listed in Table IV. In all, 21 coefficients of variation for unadjusted $\mathrm{K}$ and 21 coefficients of variation for adjusted $\mathrm{K}$ were calculated for each reference base. All but two of the adjusted were smaller than the corresponding unadjusted coefficient of variation; in both exceptional cases ranges of sodium and potassium values were small.

Analysis of covariance (to be presented in full elsewhere) showed that coefficients of variation of adjusted $\mathrm{K}$ values still depend upon whether material is from the same biopsy, muscle, or subject (Table V). Variation of material from any site in a muscle is between 7 and $39 \%$ larger than the coefficient of variation for material from a particular biopsy Those for comparing adjusted $\mathrm{K}$ observations witl展 a standard for the muscle (row 4 Table V), are regardless of reference base, almost exactly doubleू the coefficients of variation calculated from repeatech slices of a given biopsy (row 1 Table V). Those shown in the last row of Table $V$ are based on alp our data taken together, and somewhat underes estimate the coefficients of variation appropriate to adjusted $\mathrm{K}$ values irrespective of muscle and subject $-\overrightarrow{-}$

\section{DISCUSSION}

Analysis of the present data shows that sodiumpo potassium, chloride, and water contents of samples of human skeletal muscle are very variable; more $\Rightarrow \lambda$ over the average composition of different muscleg differs, even in the same individual. Variability introduced by handling samples and by errors of chemical analysis is comparatively small. The composition of adjacent slices of a muscle biopse shows marked variability and there is even greater variability between samples taken from differento parts of the same muscle, or from different muscles, or from different individuals (Table III). Increase in variability when several sites are sampled withir one muscle may be shown to be statistically signifi cant, as is the further increase when several muscles are sampled in the same individual, or one muscle is sampled in several subjects. Total variability when several muscles are sampled in one subject is muclo the same as that found when the same muscle is sampled in several subjects. Water content varie least in all circumstances, partly due to the use of wet weight of tissue as a reference base in detailing composition.

The existence of this very considerable variability in composition does not appear to have been widelg appreciated. It implies that individual electrolyte or water content of a sample of muscle is not if precise index of composition throughout the tissues

\section{TABLE V}

COEFFICIENTS OF VARIATION ( $\%$ ) OF ADJUSTED K VALUES, ACCORDING TO THE ORIGIN OF THE MATERIAL, FOR FOUR REFERENCE BASES

\begin{tabular}{|c|c|c|c|c|c|}
\hline & \\
\hline & Kilogram Wet Weight & $\begin{array}{l}\text { Kilogram Fat-Free } \\
\text { Wet Weight }\end{array}$ & $\begin{array}{l}\text { Kilogram Fat-Free } \\
\text { Dry Weight }\end{array}$ & Litre Tissue & Water \\
\hline $\begin{array}{l}\text { Different slices of same biopsy } \\
\text { Different sites in same muscle } \\
\text { Different muscles in same subject } \\
\text { Same muscle in different subjects } \\
\text { Any muscle in any subject }{ }^{1}\end{array}$ & $\begin{array}{l}4 \cdot 1 \\
5 \cdot 0 \\
8 \cdot 5 \\
7 \cdot 3 \\
8 \cdot 6\end{array}$ & $\begin{array}{l}3 \cdot 6 \\
3 \cdot 9 \\
5 \cdot 7 \\
6 \cdot 1 \\
6 \cdot 9\end{array}$ & $\begin{array}{l}3 \cdot 3 \\
4 \cdot 6 \\
6 \cdot 6 \\
7 \cdot 2 \\
8 \cdot 7\end{array}$ & $\begin{array}{l}4 \cdot 2 \\
4 \cdot 5 \\
6 \cdot 9 \\
7 \cdot 1 \\
7 \cdot 6\end{array}$ & \\
\hline
\end{tabular}

Origin Reference Base

A more orthodox approach using a small part of the data gives almost identical results.

These figures are underestimates. 
It also implies that even when sample content is compared with standards compiled from sampling the same muscle in a series of normal subjects its appraisal is blunt.

Variability is not lessened by quoting water and electrolyte contents of biopsies as amounts per kilogram of fat-free wet weight nor by using dry weight of tissue or fat-free dry weight as a reference base. But variability is largely orderly, and when account is taken of this order, residual stochastic variability is much less than the overall variability. Positive correlations exist between sample contents of sodium and chloride, and between sample contents of water and the sum of sodium plus potassium. Negative correlations obtain between sample contents of potassium and sodium except when they are quoted as amounts per kilogram of dry weight of tissue. In all cases residual variability about these relationships is much less than total variability. Quantitatively, the precise relationships between sample contents of potassium and sodium are not identical in different muscles (Fig. 7). It is unlikely that these differences were a result of differences in clinical conditions; close examination of Fig. 4 suggests that relationships differ for different muscles from the same individual. Findings illustrated in Fig. 4 also suggest that relationships for a given muscle may differ in different individuals. These observations have been subsequently confirmed by statistical analysis.

Examination of the sodium and potassium data in detail also shows that, as with total variability, residual variability is enhanced when samples are taken from different sites, in muscles or from different individuals.

These findings have a number of practical implications. 1 Because variability in composition is largely orderly, a sample affords a reasonable index of a whole muscle, when account is taken of this orderliness. If potassium is to be estimated, the sodium content of the sample should be taken into account; similarly, if chloride, the sodium content should be considered, or water, the combined amount of sodium plus potassium should be known.
2 A sample is best appraised by comparison with standards compiled by sampling the same muscle in normal subjects. It is shown that it is legitimate to compare a sample from a given muscle with standards complied by sampling several different muscles but this entails loss of precision. 3 The existence of various components of variability implies that considerable care must be taken to ensure that a coefficient of variation is appropriate to the comparison for which it is used. 4 Fat is not a major source of variability in composition. Nevertheless, fat should be estimated when tissue solids are to be used as reference base; when potassium and sodium are quoted as amounts per kilogram dry weight tissue, variability in the fat content of samples obscures the negative relationship between the contents of these two cations.

It is a pleasure to acknowledge the help offered by Professors A. L. d'Abreu, Bryan Brooke (St. George's) and F. A. R. Stammers, Mr. L. Abrams, Mr. Victor Brookes, Mr. R. K. Debenham, Mr. Arnold Gourevitch, Mr. D. Morrissey, surgeons to the Queen Elizabeth Hospital, and the sisters and their staffs of the various operating theatres at this hospital. We would like to thank Professor E. J. Conway, F.R.S., and Drs. William B. Weil and John Bull for their helpful comments on the manuscript. We are also indebted to Dr. Brenner for his critical interest throughout.

This work was supported by grants from the Endowment Research Fund of the United Birmingham Hospitals, the Royal Society, from G. D. Searle \& Co., Ltd., High Wycombe, and from the Dowager Countess Eleanor Peel Trust.

\section{REFERENCES}

Barnes, B. A., Gordon, E. B., and Cope, O. (1957). J. clin. Invest., 36, 1239.

Carpenter, R. G. In preparation.

- , and Flear, C. T. G. In preparation.

Flear, C. T. G., and Florence, I. (1961). Clin. Chim. Acta, 6, 129. - (1963). Nature (Lond.), 199, 156.

Litchfield, J. A., and Gaddie, R. (1958). Clin. Sci., 17, 483.

Mood, A. M. (1950). Introduction to the theory of statistics, p. 342. McGraw-Hill, New York.

Talso, P. J., Spafford, N., and Blaw, M. (1953a). J. Lab. clin. Med., 41, 281. 